\title{
DEEP-FREEZING OF JACKASS AND STALLION SEMEN IN CONCENTRATED PELLET FORM
}

\author{
D. KRAUSE AND D. GROVE \\ Institut für Haustierbesamung und -andrologie im Richard-Götze-Haus der \\ Tierärztlichen Hochschule, Hanover, Germany
}

(Received 31st December 1966)

Since Polge \& Rowson (1952) devised their technique of preserving bull semen at ultra-low temperatures, several attempts have been made to apply this preservation method to stallion semen.

Early reports by Szumowski (1954) and Iljinskaja (1956) were encouraging but (so far as it is known to us) later experiments conducted by Barker \& Gandier (1957), Zmurin (1959, 1960), Buell (1963), Schäfer \& Baum (1964), Polge \& Minotakis (1964) and others failed to make further progress.

However, recently, Nagase \& Graham (1964) reported an entirely new method of freezing bull semen in a pelleted form. At the same time Polge \& Minotakis (1964) found a better survival rate in jackass semen than in stallion semen, using a conventional freezing method. In conjunction with our experimental work on the seasonal influence of light on sperm production in the horse which showed a marked decrease in early winter of volume, motility and preserving ability, an attempt was made to freeze semen of both the horse and jackass using the pelleting technique.

A yolk-glucose-glycerol solution, as used by Polge \& Minotakis (1964), and yolk-citrate-glycerol-fructose extender described by Eibl, Leidl, Hahn \& Zoder (1964) proved unsuitable for this particular purpose. Therefore, three different diluents by Nagase \& Graham (1964) without any antibacterial agents were used: (a) glucose-yolk-glycerol, (b) lactose-yolk-glycerol, and (c) raffinose-yolk-glycerol.

After the usual macro- and microscopic check of the semen, it was diluted 10 to $15 \mathrm{~min}$ after collection by adding 2,3 or 5 parts, respectively, of the diluents mentioned. One part of the semen was pelleted immediately after dilution, the other two parts after 2 and $3 \mathrm{hr}$. Small droplets of semen $(0.1 \mathrm{ml})$ were placed by means of a $1-\mathrm{ml}$ pipette into holes in a slice of dry ice $\left(-79^{\circ} \mathrm{C}\right)$ where the semen freezes in about $4 \mathrm{~min}$. For storage, the pellets were transferred from dry ice into a liquid nitrogen $\left(-196^{\circ} \mathrm{C}\right)$ container.

After thawing the pellets, 50 to $70 \%$ of the spermatozoa showed progressive motility as compared with 70 to $80 \%$ in freshly collected semen. Pellets placed on a slide and thawed at $+40^{\circ} \mathrm{C}$ on the warm stage of a microscope exhibited a sperm motility of approximately 5 to $10 \%$ less than pellets which were thawed in $0.4 \mathrm{ml}$ sterile milk at $+40^{\circ} \mathrm{C}$. 
Inseminations were carried out with jackass and stallion semen preserved by the above technique, using 100 pellets thawed in 20 to $40 \mathrm{ml}$ sterile milk at $+40^{\circ} \mathrm{C}$. Palpation of the ovaries through the rectum was done in order to inseminate at the approximate time of ovulation. Three mares conceived out

TABLE 1

DETAILS OF THE A.I. TECHNIQUE EMPLOYED AND RESULTS

\begin{tabular}{|c|c|c|c|c|c|}
\hline $\begin{array}{l}\text { No. } \\
\text { of } \\
\text { mare }\end{array}$ & $\begin{array}{l}\text { No. of heat } \\
\text { periods } \\
\text { used for } \\
\text { insemination }\end{array}$ & $\begin{array}{l}\text { No. of } \\
\text { inseminations/ } \\
\text { heat period } \\
\text { ( jackass } \\
\text { semen) }\end{array}$ & $\begin{array}{l}\text { No. of } \\
\text { inseminations/ } \\
\text { period } \\
\text { (stallion } \\
\text { semen) }\end{array}$ & Result & Remarks \\
\hline 1 & 1 & 1 & & Pregnant & $\begin{array}{l}\text { At present in the second half of preg- } \\
\text { nancy. Foal is alive according to rectal } \\
\text { examination. }\end{array}$ \\
\hline 2 & 1 & 4 & & $\begin{array}{l}\text { Not } \\
\text { pregnant }\end{array}$ & - \\
\hline 3 & 1 & & 1 & $\begin{array}{l}\text { Not } \\
\text { pregnant }\end{array}$ & - \\
\hline 4 & 1 & & 3 & $\begin{array}{l}\text { Not } \\
\text { pregnant }\end{array}$ & - \\
\hline 5 & 2 & & $\begin{array}{l}3 \text { at first } \\
\text { oestrous } \\
4 \text { at second } \\
\text { oestrous }\end{array}$ & Pregnant & $\begin{array}{l}\text { Simultaneously included in a trial on } \\
\text { virus-abortion. Aborted on the 98th } \\
\text { day of pregnancy. Foal normally } \\
\text { developed according to the stage of } \\
\text { gestations.* }\end{array}$ \\
\hline 6 & 1 & & 3 & Pregnant & $\begin{array}{l}\text { At present in the second half of preg. } \\
\text { nancy. Foal is alive according to rectal } \\
\text { examination. }\end{array}$ \\
\hline
\end{tabular}

* Causative agent: Rhinotracheitis virus according to L. Lindemann and K. Petzoldt (personal communication).

of six: two after a single insemination and a third mare returned, but became pregnant with the second insemination at the following oestrus. Further details are included in Table 1.

The experimental work described will be continued during the next breeding season on a larger scale.

\section{REFERENCES}

Barker, G. A. V. \& Gandier, J. C. C. (1957) Pregnancy in a mare resulting from frozen epididymal spermatozoa. Can. 7. comp. Med., 21, 47.

Buell, J. R. (1963) A method for freezing stallion semen and tests of its fertility. Vet. Rec. 75, 900.

EIBL, K., LEIDI, W., HAHN, R. \& ZODER, H. F. (1964) Zur Rationalisierung des Einfrierprozesses von Bullensperma. Berl. Münch. tierärztl. Wschr. 77, 453.

ILjINSKajA, T. (1956) The effect of various factors on stallion spermatozoa frozen to $-70^{\circ}$. Konevodstvo, 26, (11), 32. Anim. Breed. Abstr. 25, 132 (1957).

Nagase, H. \& Graham, E. F. (1964) Pelleted semen: Comparison of different extenders and procesess on fertility of bovine spermatozoa. Vth int. Congr. Anim. Reprod. Artif. Insem. 4, 387.

Polge, C. \& Minotaxis, C. (1964) Deep-freezing of jackass and stallion semen. Vth int. Congr. Anim. Reprod. Artif. Insem. 7, 545.

Polge, G. \& Rowson, L. E. A. (1952) Long-term storage of bull semen at very low temperatures $\left(-79^{\circ} \mathrm{C}\right)$. IInd int. Congr. Anim. Reprod. Artif. Insem. 3, 90.

SchäfER, W. \& BAUM, W. (1964) Tiefgefrierung von Pferdesperma bei $-79^{\circ} \mathrm{C}$ unter Verwendung von $\mathrm{CO}_{2}$-Eis. Fortpf. Haust. 1, 105. 
Szumowski, P. (1954) Essais de congélation du sperme de cheval. C.r. hebd. Séanc. Acad. Agric. Fr. 40., 156, and Anim. Breed. Abstr. 23, 124 (1955).

Żmurin, L. M.(1959) The storage of stallion semen by freezing. Konevodstov, 29, (4), 24, and Anim. Breed. Abstr. 27, 282 (1959).

Z̈murin, L. M. (1960) Diluents for stallion semen frozen to $-20^{\circ}$. Trudȳ. vses, naǔchno-issled. Inst. Konev. 23, 95, and Anim. Breed. Abstr. 30, 157 (1962). 